Volume 11

Issue 3 Global Approaches to Atrocity

Prevention: Theory, Practice, and the State of

Article 10 the Field

3-2018

\title{
Neutrality: A Tool or a Limit for Preventing Mass Atrocitiy Crimes and Genocide? The Case of Switzerland
}

Giulia Persoz

Université de Lausanne

Follow this and additional works at: https://digitalcommons.usf.edu/gsp

\section{Recommended Citation}

Persoz, Giulia (2018) "Neutrality: A Tool or a Limit for Preventing Mass Atrocitiy Crimes and Genocide?

The Case of Switzerland," Genocide Studies and Prevention: An International Journal: Vol. 11: Iss. 3:

75-97.

DOI:

http://doi.org/10.5038/1911-9933.11.3.1507

Available at: https://digitalcommons.usf.edu/gsp/vol11/iss3/10

This Articles is brought to you for free and open access by the Open Access Journals at Digital Commons @ University of South Florida. It has been accepted for inclusion in Genocide Studies and Prevention: An International Journal by an authorized editor of Digital Commons @ University of South Florida. For more information, please contact digitalcommons@usf.edu. 


\author{
Giulia Persoz \\ Université de Lausanne \\ Lausanne, Switzerland
}

\title{
Introduction
}

Slowly opening up to the rest of the world at the end of the Cold War, Switzerland has been active in various countries and context to deal with the past and prevent mass atrocity crimes as well as genocide for many years. These activities have been institutionalized by the establishment in 2011 of a cross-departmental entity, the Task Force for Dealing with the Past and Prevention of Atrocities. Part of the wider peace promotion policy, the Task Force activities are thus a specialized area of activities in Switzerland's foreign policy. As a consequence, they are influenced by the way foreign policy is shaped and by prominent political features of the country.

The present article aims to confront the Swiss practice regarding the prevention of genocide and mass atrocities in Swiss foreign policy and its particularities shaping its international relations. Neutrality, a core part of Switzerland's identity on both the internal political level and the international level, will be at the center of our analysis. Indeed, how can a country engage in prevention activities while keeping its neutral status? How does neutrality influence these activities across time? What foreseeable impact could neutrality have on them?

Despite the institutionalization of prevention of mass atrocities and genocide several years ago, the Swiss government did not define in precise terms what falls under the label of mass atrocities and genocide, nor under the label of prevention. As we will see throughout our analysis, the lack of clear and precise definition is a constant in Switzerland's foreign policy concepts and goals. While this can be easily explained (it allows the government some leeway in its actions following international and internal political circumstances as it is not bound by a precise wording) this shortcoming is a challenge to the present article. In order to remedy to this situation and better frame what shapes prevention activities regarding mass atrocities and genocide, the article will be divided following a macro to micro logic, going from Switzerland's political and foreign policy key yet general features and principles, before addressing peace promotion, and finally mass atrocities and genocide prevention.

The present article will thus be divided as follow: the first part will be an overview of the Swiss government and the Federal Department of Foreign Affairs (A). We will then lay out Switzerland's characteristics shaping its international relations (B), especially neutrality, before presenting its foreign policy principles and objectives $(C)$, with a special focus on peace promotion policy (D). This contextualization of Swiss institutions and foreign policy aims to enable a better understanding of how activities pertaining to the prevention of mass atrocity crimes and genocide are embedded in Switzerland's political environment. The following part will present the evolution of Switzerland's activities regarding prevention of genocide and mass atrocities, as well as the actual mechanismthe Task Force Dealing with the Past and Prevention of Atrocities (E). We will consider how the Task Force is related to other areas of the government and the international community, what are its areas and countries of activities, which procedures it follows to start a project as well as the challenges it ought to overcome in the future. Finally, the last part of this article will present a critical analysis of the Swiss mechanism through the lens of its foreign policy and neutrality, to establish if-and how it is compatible with Switzerland's neutral status (F). From the conclusion reached, the article will flesh out the future of the Task Force's work in light of potential evolutions of Switzerland foreign policy and neutrality.

\section{A. Swiss Government and Federal Department of Foreign Affairs: A Brief Overview}

In order to better understand the place of mass atrocity prevention activities in the Swiss context, it is necessary to step back and give an overview of Swiss characteristics likely to influence any foreign policy decision. These factors can be internal, namely the Swiss political system, or external, the Swiss key characteristics in the international realm. The following part gives a brief overview of the Swiss political system and government. 
Since 1848, Switzerland has been a democratic federal state composed of 26 regional states called cantons. Its political form is a direct consequence of the country's heterogeneous nature: with four national languages (German, French, Italian and Romansch), different cultures and religions, Switzerland's population is extremely diverse. The Swiss political system is thus a multi-ethnic federalism, an alternative to the nationalist integration strategy that prevailed in Europe during the 19th century. ${ }^{1}$ Similar to the American model, the Parliament follows a bicameral system. It is composed of two chambers (the National Council and the Council of States), both representing the cantons. ${ }^{2}$ The executive branch of the government, however, differentiates itself from the United States: instead of having a government lead by a powerful single presidential figure, the leadership of the country is assumed by a council composed of seven equally powerful ministers, elected by the Parliament every four years. ${ }^{3}$ Each year, one of its member assumes the role of President of the Federation. However, while they are considered head of state, they enjoy no special political privileges. ${ }^{4}$

Democracy in Swiss political culture is not perceived as a majoritarian democracy but as a consensus democracy. Thus the Swiss perceive that "[...] conflicts are resolved not on the basis of narrow and shifting majorities, but rather through negotiations leading to a clear majority or even total consensus." ${ }^{5}$ Conceptualizing politics this way yields two consequences. First, political bodies should be drawn from all important groups (linguistic, geographic, etc.). ${ }^{6}$ Secondly, Federal Council decisions should be taken collegially. As such, deliberations within the Council should be led jointly, aiming for consensus. ${ }^{7}$ If consensus is unachievable, then the decision should be taken following the majority principle. However, once the decision is made, each Councilor must back it even if they originally adhered to the overruled minority. ${ }^{8}$

Another strong political feature of the Swiss system is direct democracy. At the federal level, referenda are mandatory for all constitutional amendments, as well as the ratification of treaties concerning membership in international collective security organizations or supranational bodies. ${ }^{9}$ The system also allows in the case of federal legislation, or permanent international treaties that provide an accession to an international organization, that contain important legislative provisions or whose implementation requires the enactment of additional federal legislation, for an optional referendum when requested by 50,000 citizens or eight cantons. ${ }^{10}$ If the voting population rejects the act or treaty, it cannot be passed or ratified. In addition to this post-facto procedure of democratic control, Swiss citizens also possess a right of initiative to modify the Federal Constitution. ${ }^{11}$ Onehundred thousand citizens have to petition for the initiative to be put to vote. ${ }^{12}$

These features have a strong impact on foreign policy making. Within the government, the lack of outright opposition, as well as the lack of election of individuals based on specific foreign policy goals, and the slow decision-making process inherent in collegiality help shape the way the

\footnotetext{
${ }^{1}$ Adrian Vatter, "Federalism," in Handbook of Swiss Politics, ed. Peter Knoepfel et al., $2^{\text {nd }}$ ed. (Zürich: Neue Zürcher Zeitung Publishing, 2007), 78-79.

${ }^{2}$ Tbid., 78.

${ }^{3}$ Government of Switzerland, Federal Constitution of the Swiss Confederation, 18 April 1999, as of 1 January 2016, RS 101, art. 174 and 175 (hereinafter FC). An official English version is online, accessed December 28, 2017, https://www.admin.ch/ opc/en/classified-compilation/19995395/index.html.

${ }^{4}$ Ülrich Klöti, “The Government,” in Handbook of Swiss Politics, ed. Ülrich Klöti, $2^{\text {nd }}$ ed. (Zürich: Neue Zürcher Zeitung Publishing, 2007), 145.

${ }^{5}$ Ibid., 149.

${ }^{6}$ Ibid.

${ }^{7}$ FC, Art. 177.

${ }^{8}$ Klöti, The Government, 155-156.

${ }^{9}$ FC, Art. 140.

${ }^{10}$ FC, Art. 141.

${ }^{11} \mathrm{FC}$, Art. $138-139$.

${ }^{12}$ For more on Swiss direct democracy: Wolf Linder, "Direct Democracy," in Handbook of Swiss Politics, ed. Peter Knoepfel et al., $2^{\text {nd }}$ ed. (Zürich: Neue Zürcher Zeitung Publishing, 2007), 101-119.
} 
country is run. ${ }^{13}$ Moreover, referendum and initiatives can modify Swiss foreign policy, more often than not impeding a possible active and integration-based role in favor of a more protectionist approach. ${ }^{14}$ Swiss citizens strongly identify with the state's emblematic political specificities (namely federalism, collegiality, concordance and direct democracy). They want to preserve this combined approach and are extremely reluctant to change it, especially when they feel pressured to do so by a foreign interference. ${ }^{15}$

In Switzerland, state competences are divided between cantons and federal authorities, which are called the Confederation, on the basis of the Federal Constitution (hereinafter cited as FC). The Confederation's executive branch has the task of implementing the law enacted by the legislature and is divided into seven Departments, each led by a member of the Federal Council: the Federal Department of Foreign Affairs, the Federal Department of Home Affairs, the Federal Department of Justice and Police, the Federal Department of Defense, Civil Protection and Sport, the Federal Department of Finance, the Federal Department of Economic Affairs, Education and Research, and the Federal Department of the Environment, Transport, Energy and Communications. ${ }^{16}$

Mass atrocities and genocide prevention activities fall within the competence of the Federal Department of Foreign Affairs (hereinafter FDFA). The FDFA is responsible for implementing Switzerland's foreign policy and for protecting its interests abroad. ${ }^{17}$ In addition to its network of Missions, embassies and other representations abroad, the head office of the FDFA is subdivided into eight departments, each pertaining to a special theme. The State Secretariat is responsible for the maintenance, development and coordination of Switzerland's bilateral relations with other States, as well as its multilateral foreign policy. The background work central to the proper running of the FDFA such as the development of foreign policy goals and strategies, as well as the identification of the current trends, challenges and risks is done by the Directorate of Political Affairs. The Directorate itself is organized into sections focusing on bilateral relations, multilateral relations, sectoral foreign policies, security policy and human security. Given the importance that Switzerland attaches to the European Union, a special Directorate for European Affairs has also been established. In addition to this political core, the FDFA also encompasses of the Swiss Agency for Development and Cooperation, which is responsible for the coordination of development activities and cooperation Switzerland undertakes, as well as for the humanitarian aid; the Directorate of International Law; the Consular Directorate; the General Secretariat; and the Directorate for Resources. $^{18}$

\section{B. Key Characteristics of Switzerland's International Relations}

As stated above, while collegiality, consensus and direct democracy have an impact on foreign policy decision, the Swiss government is influenced by several other external factors. The section below addresses three key characteristics likely to shape foreign policy either during its decisionmaking phase: Switzerland's small state status; neutrality; and/or during its implementation, a lack of colonial past.

Within the international community, Switzerland is distinguished from other states by several characteristics. First, Switzerland is a relatively small state. Surrounded by big European powers such as France or Germany, Switzerland has, from its historical creation in 1291 until today, been "a small state surrounded by much larger nations" whose "existence depended on the good will

${ }^{13}$ Jürg Martin Gabriel, "The Price of Political Uniqueness: Swiss Foreign Policy in a Changing World," in Swiss Foreign Policy 1945-2002, eds. Gabriel, Jürg Martin et al. (London: Palgrave Macmillan, 2003), 9.

${ }^{14}$ The paramount example is Switzerland's integration to the European Union: while it was a goal for the Federal Council to integrate the EU, repetitive plebiscites made it clear that Swiss citizens were against it. The Swiss government had to modify its approach and chose to pursue strong bilateral agreements instead.

${ }^{15}$ Gabriel, The Price of Political Uniqueness, 8.

${ }^{16}$ Government of Switzerland, Ordonnance sur l'organisation du gouvernement et de l'administration, 25 November 1998, as of 1 August 2016 (RS 172.010.1), Annex 1.

${ }^{17}$ Government of Switzerland, Ordonnance sur l'organisation du Département fédéral des affaires étrangères, 20 April 2011, as of 24 March 2015 (RS 172.211.1), art. 1.

${ }^{18}$ Ibid., art. 7-11; Government of Switzerland, Federal Department of Foreign Affairs, "Organisation of the FDFA," March 10, 2016, accessed September 4, 2016, https://www.eda.admin.ch/eda/en/home/fdfa/organisation-fdfa.html. 


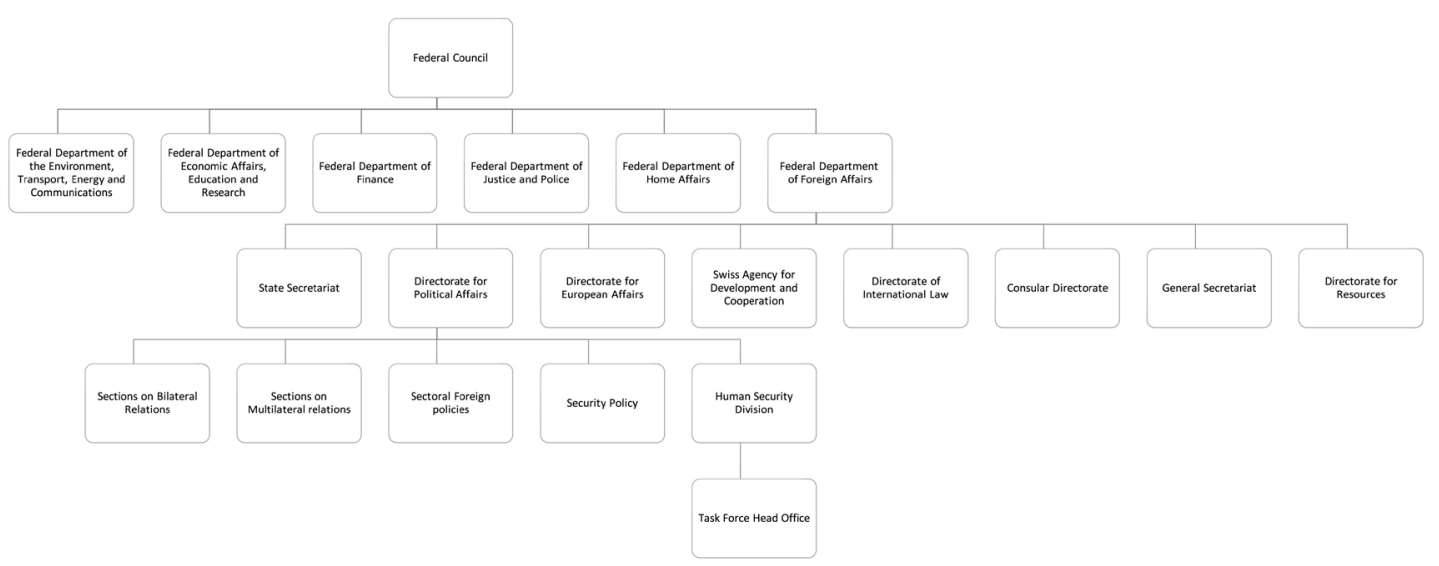

Figure 1. The full-size version of this figure can be downloaded at http://doi.org/10.5038/19119933.11.3.1507.

of these neighbours."19 The potentially threatening bigger neighbors have had a large impact in shaping the Switzerland's foreign policy. That policy simultaneously pursued two different aims: to guarantee the collective defense of the Confederation against intruders while remaining neutral, and to ensure that its powerful neighboring states would not view its defensive policies as provocative. ${ }^{20}$ According to Graf and Lanz, "the two World Wars, in which Switzerland remained uninvolved, solidified the image that Switzerland, being smaller and less powerful than its neighbours, should refrain from competing with the big powers but adopt a niche foreign policy in order to maintain its independence." ${ }^{21}$

Secondly, and as a consequence of its small-state status and geographical situation, Switzerland has chosen to remain neutral when faced with conflicts throughout Europe. ${ }^{22}$ Neutrality was the political response Switzerland devised to counter its vulnerability among European greater powers: it allowed the country to protect its sovereignty and placed the principle of non-interference, the fundamental mantra of small-state diplomacy, at the core of Swiss foreign policy. ${ }^{23}$ Some have argued that neutrality stood for the absence of foreign policy. ${ }^{24}$ But Goetschel was probably more accurate when he underlined that "neutrality was actually a strategy for survival."25

It is not evident to establish prima facie how neutrality affects Switzerland's foreign policy, and, in extenso, its mass atrocities prevention activities. In order to do so, it is necessary to layout what entails neutrality for the Swiss government, and how it evolved through time according to the international circumstances. In subsequent section (F), Switzerland's approach to mass atrocity and genocide prevention will be analyzed through the lens of this conceptual framework.

Swiss neutrality can be traced back to the battle of Marignano in 1515, however its status as a permanent neutral state has been formally recognized by the international community only since the Congress of Vienna in 1815. ${ }^{26}$ Since then, Switzerland has ratified in 1910 the two international

\footnotetext{
${ }^{19}$ Laurent Goetschel, Magdalena Bernath, and Daniel Schwarz, Swiss Foreign Policy: Foundations and Possibilities (Milton Park: Routledge, 2005), 14.

${ }^{20}$ These two ideas can still be found today in FC, Art. 173 and Art. 185.

${ }^{21}$ Andreas Graf and David Lanz, “Conclusions: Switzerland as a Paradigmatic Case of Small-state Peace Policy?" Swiss Political Science Review 19 (2013), 412.

${ }^{22}$ Laurent Goetschel, "Foreign Policy," in Handbook of Swiss Politics, ed. Peter Knoepfel et al., $2^{\text {nd }}$ ed. (Zürich: Neue Zürcher Zeitung Publishing, 2007), 573.

${ }^{23}$ Andrew Cooper and Timothy Shaw, "The Diplomacies of Small States at the Start of the Twenty-first Century: How Vulnerable? How Resilient?" in The Diplomacies of Small States: Between Vulnerability and Resilience, ed. Andrew Cooper et al. (New York: Palgrave Macmillan, 2009), 5.

${ }^{24}$ Gabriel, The Price of Political Uniqueness, 15.

${ }^{25}$ Goestchel, Foreign Policy, 573.

${ }^{26}$ Stefan Aeschimann et al, Swiss Neutrality, 4th ed. (Bern: Communication DDPS, 2004), 10.
} 
conventions respecting the rights and duties of neutral Powers. The status of a neutral state invokes rights and duties for both the neutral state and the belligerents states in times of conflict. ${ }^{27}$ While it is a political choice to abide by neutrality law, its consequences are of a legal nature. ${ }^{28}$ Neutrality law can be summed up as follow: as long as the actions of the neutral state do not interfere with an armed conflict, impeding or giving an advantage to one side or the other, the neutral state benefits from a special protection from the consequences of the conflict (such as the interdiction for the belligerents to militarily use its territory). ${ }^{29}$ Moreover, any action taken by a neutral state in order to protect its neutrality cannot be qualified as a hostile act by parties to the conflict. ${ }^{30}$

A State can decide to stay neutral with regard to a specific and delimited armed conflict (occasional neutrality achieved by an ad hoc declaration), however Switzerland has chosen to remain permanently neutral. This implies that it stays neutral at all times, with respect to all conflicts. Although ad hoc neutrality applies only in times of war, permanent neutrality also creates duties for neutral state in times of peace: the neutral state cannot bind itself to any military obligations nor act in a way that would impede the realization of its duties if an armed conflict were to arise. ${ }^{31}$ In other words, a permanent neutral state promises not to enter into preventive alliances, ${ }^{32}$ and can only enter a defensive alliance in reaction to a perceived threat. ${ }^{33}$

Conceptually, neutrality has served two security purposes for Switzerland. On the one hand, it has protected the country from foreign interference. On the other hand, it has also proved useful to achieve domestic stability. ${ }^{34}$ As mentioned above, Switzerland is a heterogeneous country composed of several religions, languages and cultures. Given its lack of common identity, internal cohesion has never been set in stone, especially in times of European tension. For instance, the Swiss population was divided over whom to follow during the 16th century's era of religious conflicts, as well as during the two World Wars. Picking a side would have led to internal crisis. Thus, neutrality avoided a potential national implosion. ${ }^{35}$

It is worth noting that while the security and the independence of the country are mentioned in Article 2(1) of the FC, which specifies the aims of the Confederation, neutrality has been purposely left out. Neutrality actually only appears twice within the federal Constitution: Articles 173(1) and 185(1) give to the Federal Council and to the parliament the power and duty to take "measures to safeguard external security and the independence and neutrality of Switzerland." As a consequence, though neutrality is a central maxim that shapes Swiss foreign policy, it has to be considered not as an aim per se but as a flexible tool which can be used to foster its independence and security. ${ }^{36}$

This flexibility is made possible by the distinction between neutrality law and policy of neutrality. All measures taken by the Swiss government that exceed its legal duties as enshrined in neutrality law are defined by its policy of neutrality. ${ }^{37} \mathrm{~A}$ neutral state must $a$ minima ensure the respect of the relatively narrow neutrality law, but can make a political choice to go further. In

\footnotetext{
${ }^{27}$ Michael Bothe, "The Law of Neutrality," in The Handbook of International Humanitarian Law, ed. Dieter Flecker, 3rd ed. (New York: Oxford University Press, 2013), 549.

${ }^{28}$ Ibid., 554.

${ }^{29}$ Leslie Green, The Contemporary Law of Armed Conflict, 3rd ed. (Manchester: Manchester University Press, 2008$), 297$.

${ }^{30}$ Ibid., 305.

${ }^{31}$ Ibid.

${ }^{32}$ For instance, a neutral State cannot enter a military alliance such as NATO. The principle of collective defence as enshrined in Article 5 of the North Atlantic Treaty would go against its neutral state duties in case of an aggression.

${ }^{33}$ The threshold that allows the shift between preventive and reactive alliance is the gravity of subjective notion of the perceived threat. If it is considered as grave, "[...] caution would dictate the planning of a preventive alliance and the establishing of first (and secrets) contacts. The Swiss did just that in two World Wars [...]." Gabriel, The Price of Political Uniqueness, 11.

${ }^{34}$ Aeschimann et al., Swiss Neutrality, 3 .

${ }^{35}$ Ibid.; Gabriel, The Price of Political Uniqueness, 9.

${ }^{36}$ Government of Switzerland, Federal Council, White Paper on Neutrality, Annex to the Report on Swiss Foreign Policy for the Nineties, November 29, 1993 (FF 1994 I 150), 7.

${ }^{37}$ Ibid., 8.
} 
this regard, "neutral politics have the function of protecting the credibility of neutral law." ${ }^{38}$ For the Federal Council, this possibility gives to Switzerland a large freedom of action. ${ }^{39}$ The Council even considers that there is only one immutable principle in regard to its neutral status: the noninvolvement in an international armed conflict. ${ }^{40}$

For the Swiss government, neutrality is a flexible instrumental concept that should be used to best serve the country's interests, namely its independence and security.$^{41}$ In that regard, the Federal Council considers it necessary to adapt its policy of neutrality to changing international circumstances. The Council justifies this approach not as a case of opportunism but as a way to preserve Switzerland's stability and predictability. ${ }^{42}$ This concept implies that if neutrality were to be unable to best protect and preserve the country's independence and security, Switzerland could renounce to its neutral status.

From the Second World War until the end of the Cold War, Switzerland has followed a strict policy of neutrality, going so far as to refuse, in the name of neutrality, to adhere to international economic sanctions for a limited amount of time. ${ }^{43}$ Perceived by the population as the reason why the country made it out of the Second World War relatively unscathed, neutrality was more and more considered as an end unto itself rather than as an instrument of foreign policy. ${ }^{44}$ Despite the weakening of the nation-state era and the beginning of a new trend towards multilateralism and integration, as well as the radical power balance shift brought on by the end of the Second World War, this conception remained unquestioned for more than four decades.

From the end of the Cold War, the shift from a bipolar to a multipolar world with the rise of new kinds of cross-border threats such as international terrorism, organized crime, environmental issues, etc., the strict understanding of neutrality that prevailed was no longer considered sufficient to ensure Switzerland's independence and security. In 1993, reconsidering its foreign policy according to the changes occurring since 1945, Switzerland shifted from its traditional, more isolationist interpretation of neutrality to a more flexible approach. ${ }^{45}$ This new approach, called active neutrality, allowed for expanding its humanitarian activities and security policy, namely by increasing its cooperation with other states in order to fight and prevent these new threats. ${ }^{46}$ Two consequences arose from the government's 1993 White Paper on Neutrality: first, it somewhat reduced the importance of neutrality ${ }^{47}$ Secondly, it subordinated neutrality to the principle of solidarity. ${ }^{48}$ Indeed, according to the White Paper, for Switzerland to stay useful to the international community, "neutrality needs to be interpreted in light of the requirements of international solidarity and should be used to serve of the international community and world peace." 49

Despite this redefinition, Swiss neutrality still plays an important role nowadays. While the obligations deduced from its neutrality policy have been gradually scaled back in the wake of the Cold War, Switzerland's status as a neutral state was publicly reaffirmed by the Federal Council. ${ }^{50}$ This apparent dichotomy can be explained by the role of neutrality as a cohesion factor: as Goetschel argues, "[neutrality's] role as an identity provider has become neutrality's most important function

\footnotetext{
${ }^{38}$ Gabriel, The Price of Political Uniqueness, 10.

${ }^{39}$ Switzerland, Federal Council, White Paper on Neutrality, Annex to the Report , 7.

${ }^{40}$ Ibid.

${ }^{41}$ Ibid., 9 .

${ }^{42}$ Ibid., 7.

${ }^{43}$ Aeschimann et al., Swiss Neutrality, 6.

${ }^{44}$ Gabriel, The Price of Political Uniqueness, 12.

${ }^{45}$ The 1993 White Paper on Neutrality from the Federal Council brought Swiss foreign policy in line with both multilateralism and collective security. Gabriel, The Price of Political Uniqueness, 20.

${ }^{46}$ Switzerland, Federal Council, White Paper on Neutrality, Annex to the Report, 27.

${ }^{47}$ Jürg Martin Gabriel, “Neutralität für den Notfall: Der Bericht des Bundesrats Zur Aussenpolitik der Schweiz in den 90er Jahren," Swiss Political Science Review 1 (1995), 129-158.

${ }^{48}$ Switzerland Federal Council, White Paper on Neutrality, Annex to the Report, 27.

${ }^{49}$ Ibid., 11.

${ }^{50}$ Goetschel, Foreign Policy, 574.
} 
since the end of the Cold War." ${ }^{11}$ Indeed, a large majority of the population still continues to believe that the country's foreign policy should be based on neutrality. ${ }^{52}$ Direct democracy ensures that Swiss foreign policy makers do not stray too far away from this popular conception, including in peace promotion and prevention activities.

As popular but also foreign policy makers conception of neutrality and Switzerland's role in the international realm does not always equate to the legal definition of neutrality, it is necessary to ask oneself how this Switzerland's characteristics are likely to influence its foreign policy. Drawing on Holsti typology, ${ }^{53}$ Graf and Lanz consider the tendency to isolationism, a corollary to Switzerland's small and neutral state status, as one of its national role conception - which they define as a "state's self-image as well as the expectations it perceives from the outside world [that] are incorporated into the foreign policy-making process." ${ }^{54}$ According to Holsti, "the national role of the isolate demands [...] a minimum of external contacts of whatever variety. [It] reveals fears of external involvements of any kind and emphasizes self-reliance." ${ }^{55}$ Switzerland's isolate national role conception should however be nuanced. While neutrality may play a great part in shaping a protectionist approach, placing independence and sovereignty at the core of Swiss foreign policy, other interests and characteristics may have a clashing impact. In that sense, Gabriel considers that Switzerland suffers from dualism: "economically, scientifically, and culturally the country is extremely interdependent internationally, while at the same time it places extraordinary emphasis on maintaining its independence." ${ }^{16}$ As a consequence, he makes a distinction between "high politics" (namely security and other areas of high political importance where the Swiss are more protectionist) and "low politics" (related to well-being and technical areas where the Swiss are more likely to be internationalist). ${ }^{57}$ One could argue that given this dualism, Switzerland could be considered independent instead of isolate, as it lacks the fear element. Indeed, in accordance with Holsti's definition of independent government, Switzerland stresses the element of selfdetermination and interest-driven foreign policy, as we will see below..$^{58}$

Graf and Lanz recognize a second Swiss national role conception: the role of mediatorintegrator. Holsti defines mediator-integrator governments as governments perceiving

[...] themselves as capable of, or responsible for, fulfilling or undertaking special tasks to reconcile conflicts between other states or groups of states. (Statements that referred to a mediatory role in only one specific crisis were not counted.) The themes for this national role conception indicate perceptions of a continuing task to help adversaries reconcile their differences. ${ }^{59}$

As the isolate national role conception, the role of mediator-integrator is a direct consequence of Switzerland's neutrality. Neutrality often entails an idealistic dimension, which compels neutral states to promote world peace through their services. This semblance of missionary faith can be explained following a utilitarian logic. According to Goetschel, "neutrals felt the need to highlight their own role in the international system, and for this purpose they conceived their policy as

\footnotetext{
${ }^{51}$ Laurent Goetschel, “Neutrality, a Really Dead Concept?” Cooperation and Conflict 34 (1999), 132.

${ }^{52}$ According to the annual security studies by the Swiss Military College at the Federal Institute of Technology in Zurich, from 1993 to 2004, between $80 \%$ to $90 \%$ of the population thought that Switzerland should retain its neutrality; see as well Jean-Marc Rickli, "Neutrality Inside and Outside the EU: A Comparison of Austrian and Swiss Security Policies after the Cold War," in Small States in Europe: Challenges and Opportunities, ed. Robert Steinmetz et al. (Surrey: Ashgate, 2010), 181-198.

${ }^{53}$ Kalevi Jaakko Holsti, “National Role Conceptions in the Study of Foreign Policy,” International Studies Quarterly 14 (1970), 233-309.

${ }^{54}$ Graf et al., Conclusions, 411.

${ }^{55}$ Holsti, National Role Conceptions, 270.

${ }^{56}$ Gabriel, The Price of Political Uniqueness, 1.

${ }^{57}$ Ibid.

${ }^{58}$ It could even be argued that its interest-driven foreign policy may lead to an "active-independent" instead of a solely "independent" national conception role. Holsti, National Role Conceptions, 268 and 262.

${ }^{59}$ Ibid., 265.
} 
something 'higher', like an ideal of justice." ${ }^{60}$ The mediator-integrator role is for instance embodied in the Swiss traditions of providing good offices in situations of conflicts. Switzerland can either offer its protecting power or can position itself as a facilitator in the mediation process. ${ }^{61}$ Another example is the longstanding Swiss humanitarian tradition-a reference to this long-time tradition is present since the beginning of Switzerland constitutional history, in $1848 .{ }^{62}$

A priori contradictory, the isolate and the mediator-integrator national role conceptions are another dualism in Swiss foreign policy. Both roles co-exist as they are traditionally associated with different political trends and groups within Switzerland. One or the other can prevail at different moment in time according to the evolving circumstances of the international world. As we mentioned earlier, the Cold War era led to the prevalence of the isolate role conception, while since 1993, a more flexible approach of neutrality has allowed a more active mediator-integrator role. While peace promotion appears to be a logical extension of a strong mediator-integrator role, activities in the field are not completely put to a stop whenever the other conception prevails. Peace promotion, during tense period, is a way to demonstrate Switzerland's usefulness to greater powers. ${ }^{63}$

While Graf and Lanz limit themselves to two Swiss national conceptions, it can be argued that other role conceptions defined by Holsti apply to Switzerland. To name a few, Switzerland could also be considered as a bridge state, which completes its mediator-integrator role as it searches to build bridges between different in times of war and peace. ${ }^{64}$ Indeed, as Didier Burkhalter, Federal Councilor in charge of Foreign affairs from 2009-2017, stated: "the idea of bridge-building is also an intrinsic part of Switzerland's identity and foreign policy. It is part of our political DNA. As a multiethnic country with four national languages, Switzerland has relied on dialogue and compromise to ensure its domestic cohesion for centuries." ${ }^{65}$ It could also be argued that the government considers itself bound by the defender of the faith national role conception in relation to its tradition of promoting humanitarian value. ${ }^{66}$

Last external factor likely to influence Switzerland's foreign policy activities, whereas the majority of European States have historically been involved on other continents, Switzerland has no colonial past. As a consequence, Switzerland benefits from a broader flexibility to undertake actions and programs with a broader array of international partners. This characteristic, in opposition to the ones mentioned above, may not have a significant impact in foreign policy making process. However, it may give to Switzerland a greater freedom of action in its implementation. For instance, peace promotion activities from former colonial powers may sometimes be considered as a new form of colonial interferences and be refused on that basis. Both the lack of colonial past and neutrality give to Switzerland a comparative advantage in its international relations. ${ }^{67}$

\section{Swiss Foreign Policy's Principles and Objectives}

To understand how Switzerland's activities regarding mass atrocities and genocide prevention are enshrined within Swiss foreign policy, it is necessary to go beyond external and internal factors shaping foreign policy and define what exactly stems from them and constitutes Swiss foreign policy's principles and objectives. As a consequence from Switzerland's limited power as a small state, as well as its neutrality, direct democracy and federalism, Swiss foreign policy historically

\footnotetext{
${ }^{60}$ Goetschel, Neutrality, 120.

${ }^{61}$ Government of Switzerland, Federal Department of Foreign Affairs, “Good Offices,” December 18, 2017, accessed February 7, 2018, https://www.eda.admin.ch/eda/en/home/foreign-policy/human-rights/peace/switzerland-s-goodoffices.html.

${ }^{62}$ Graf et al., Conclusions, 413.

${ }^{63} \mathrm{Ibid}$.

${ }^{64}$ Holsti, National Role Conceptions, 266-267.

${ }^{65}$ Government of Switzerland, Federal Council, "Good Offices: A Swiss Speciality" (speech, Valetta, September 15, 2016), accessed October 3, 2016, https://www.admin.ch/gov/de/start/dokumentation/medienmitteilungen.msg-id-60927.html.

${ }^{66}$ Holsti, National Role Conceptions, 264.

${ }^{67}$ Government of Switzerland, Federal Department of Foreign Affairs, For Peace, Human Rights and Security: Switzerland's Commitment to the World. Bern, 2012, 3.
} 
has not been accorded particularly high importance. ${ }^{68}$ Until the end of the Cold War, Switzerland usually privileged the preservation of its independence through neutrality over its international influence. ${ }^{69}$ In the old Federal Constitution, foreign policy was given a single goal: to preserve Switzerland's independence. ${ }^{70}$ Yet, the circumstances have changed. Switzerland has not been viewed as a small state since the end of the Second World War. Globalization and integration tend to question the viability and feasibility of a foreign policy based on independence. ${ }^{71}$ However, due to its political characteristics and its conception of its national role, changes in Switzerland happen very slowly. ${ }^{72}$

As mentioned above, the reconsideration of Swiss foreign policy in a post-Cold War conflict led to a new approach to neutrality. More importantly, the extremely narrow foreign policy that prevailed until then was considered inadequate. ${ }^{73}$ The protection of Swiss sovereignty as the sole goal of the country's foreign policy was abandoned in favor of a cluster of five programmatic goals. ${ }^{74}$ Originally issued in the 1993 Foreign Policy Report, the goals were included in the revised Federal Constitution of 1999, currently in force.

According to the revised Constitution, foreign relations are primarily the responsibility of the federal government. ${ }^{75}$ Cantons only benefit from a limited role in shaping Switzerland's foreign policy, as they shall be consulted only if the decision affects their powers or their essential interests. ${ }^{76}$ The Constitution establishes overlapping responsibilities of the government and the parliament. Special committees of both chambers on foreign policy thus enjoy a consultative role. The Parliament in full form addresses only the most important treaties. ${ }^{77}$ Swiss people benefits from a broad range of opportunities to shape foreign policy, consequence of direct democracy. The electorate enjoys a right of initiative on matters related to foreign policy as well. The sole limit of this right is that initiatives must respect mandatory international law to be considered valid. ${ }^{78}$ Moreover, constitutional guidelines foresee a mandatory and an optional referendum on international treaties. ${ }^{79}$

In addition to the potential limits put by the Parliament or the Swiss population, the government does not enjoy a complete liberty to elaborate foreign policy aims and strategies. Article 2 FC defines the overall aims of the Swiss government and states that: "[the Swiss Confederation] is committed [...] to a just and peaceful international order." ${ }^{80}$ More precisely, Article 54 (2) FC gives the Confederation the duty to "[...] ensure that the independence of Switzerland and its welfare is safeguarded; it shall in particular assist in the alleviation of need and poverty in the world and promote respect for human rights and democracy, the peaceful co-existence of peoples as well as the conservation of natural resources." ${ }^{\prime 1}$

Article 54 (2) FC upheld the five programmatic goals established in 1993. In defining its foreign policy, the government should equally aim to 1) maintain and promote peace and security; 2) enhance human rights, democracy and the rule of law; 3) advance prosperity; 4) reduce social inequalities; and 5) protect the natural environment. However, these goals have to be understood

\footnotetext{
${ }^{68}$ Goetschel, Foreign Policy, 573.

${ }^{69}$ Ibid., 587.

${ }^{70}$ Jürg Martin Gabriel and Jon Fanzun, Swiss Foreign Policy: An Overview (Zürich, ETH Zürich - Forschungsstelle für Internationale Beziehungen, 2003), 3.

${ }^{71}$ Goetschel, Foreign Policy, 757 and 587.

${ }^{72}$ In 2003, Gabriel and Fanzun considered that political changes to adapt to the post-Cold War era had only "merely begun." Gabriel et al., Swiss Foreign Policy, 3.

${ }^{73}$ Ibid.

${ }^{74}$ Gabriel, The Price of Political Uniqueness, 21-22; Gabriel et al., Swiss Foreign Policy, 3.

${ }^{75} \mathrm{FC}$, Art. 54.

${ }^{76}$ FC, Art. 55(1).

${ }^{77}$ Goetschel, Foreign Policy, 578.

${ }^{78}$ FC, Art. 139(3).

${ }^{79}$ FC, Art. $140-141$.

${ }^{80} \mathrm{FC}$, Art. 2(4).

${ }^{81}$ FC, Art. 54 (2).
} 
as an expression of the duty "to ensure that the independence of Switzerland and its welfare is safeguarded," considered by Goetschel as the "supreme goal" of Swiss foreign policy. ${ }^{82}$ The revised Constitution thus adds the notion of welfare to the traditional goal of independence. In comparison with the 1993 Report, it specifically provides a special treatment to trade policy, giving to the government a task to safeguard Swiss economy's interest abroad. ${ }^{83}$ It is interesting to note that the two national role conceptions of Graf and Lanz can be linked to this segmentation - the supreme goal might be attached to the national role of the isolate, while the five programmatic goals might be an expression of the mediator-integrator national role. As such, undertaking activities of prevention of mass atrocities and genocide seem to easily fall within most, arguably all, five clusters. They must however always be taken in accordance with Switzerland's independence and its welfare.

The elaboration and implementation of foreign policy is primarily the task of the FDFA. As we saw, the FDFA is divided in several units, usually given different theme of foreign policy. This subdivision is subjective. Subjects are often cross-sectional: while the lead role is usually the task of a specific unit, coordination and consultation of relevant divisions, sometimes even outside the FDFA, are planned in internal procedure (consultation with the offices). Goestchel argues that the adoption of five thematic goals of foreign policy is an expression of the thematic specialization within the FDFA. ${ }^{84}$

The overall constitutional aims are concretized through foreign policy reports and strategies. They follow the implementation principles traditionally governing Swiss foreign policy, among which neutrality, universality, dialogue, efficiency and coherence, solidarity and responsibility. Indeed, according to the Swiss government, the importance of a State within the international community is also measured by its responsible commitment to face global challenges in solidarity with other States. While the principle of universality implies that Switzerland searches to maintain good relationships with every States, it does not mean a lack of priority. Actions are privileged wherever Switzerland can make a substantial contribution. Following a logic of efficiency, thematic and geographic priorities are periodically redefined according to Swiss interests and area of competences. ${ }^{85}$

In the heart of Europe, Switzerland has since long put an emphasis on European States in its foreign policy. Since 2005, Great Powers, economically powerful countries, or countries with whom Switzerland has strong economic ties are also awarded a special position (in particular US, Russia, China, Brazil, India, Japan, and South Africa). Another special focus has been set on South East Europe since the Balkan war, motivated by the proximity of the conflict menacing Europe's stability, as well as the migratory impact the war had on Switzerland. The importance of the Middle East has also grown over the past few years. ${ }^{86}$

Currently, Switzerland's foreign policy is defined by the 2016-2019 Foreign Policy Strategy, explained by a Message of the Federal Council to the Parliament. ${ }^{87}$ During that lapse of time, Swiss foreign policy will be embodied in four interlinked strategic priorities: relations with the European Union and the EU and EFTA member states, relations with global partners, peace and security, and finally sustainable development and prosperity..$^{88}$ According to the Strategy, Switzerland pursues a pragmatic, citizen-oriented foreign policy, which, while flexible to rapidly changing international

\footnotetext{
${ }^{82}$ Goetschel, Foreign Policy, 577.

${ }^{83}$ FC, Art. 101.

${ }^{84}$ Goetschel, Foreign Policy, 582.

${ }^{85}$ Government of Switzerland, Federal Council, Swiss Foreign Policy Strategy 2016-9: Federal Council report on the priorities for the 2016-19 legislative period, Bern: Federal Department of Foreign Affairs, 2016, 7.

${ }^{86}$ Government of Switzerland, Federal Council, Rapport sur la politique extérieure 2000, Présence et coopération: la sauvegarde des intérêts dans un monde en cours d'intégration, November 15, 2000 (FF 00.09); Government of Switzerland, Federal Council, Rapport de politique étrangère, June 15, 2007 (FF 07.058); Government of Switzerland, Federal Council, Rapport sur la politique extérieure 2015, January 13, 2016 (FF 16.009).

${ }^{87}$ Switzerland, Federal Council, Swiss Foreign Policy Strategy 2016-9: Federal Council report.

${ }^{88}$ Ibid., 5.
} 
circumstances, is in continuity with previous strategies. ${ }^{89}$ Moreover, it considers that Switzerland is comparatively well placed within the international community and enjoys considerable soft power. $^{90}$

\section{Peace Promotion in Switzerland's Foreign Policy}

The comprehensive overview of what constitutes and shapes Switzerland's foreign policy gives us the necessary context to understand Swiss political choices regarding peace promotion, and in extenso, mass atrocities and genocide prevention. The section below will thus take a closer look at the field of peace promotion, before the subsequent section can address Switzerland's approach to preventing mass atrocities and genocide.

With one out of the five objectives enshrined in the federal Constitution and a specific division working towards its realization, peace promotion is an important part of Switzerland's foreign policy ${ }^{91}$ In that matter, Switzerland core objective is to "[...] build on its commitment to peace and security, lending significant impetus to a viable an just international order." ${ }^{\prime 2}$ It is ensured by mediation and crisis diplomacy, as well as the promotion human rights, fighting against terrorism, and a continuous commitment to international law.

The argument used to pursue the objective on peace and security is twofold within the 20162019 Foreign Policy Strategy. First, it underlines the recent unrest development worldwide and the negative reverberations it has for Switzerland. Indeed, "as a highly globalized country with an export-oriented economy, Switzerland depends for its security and prosperity on a stable environment and a viable an just international order." ${ }^{\prime 93}$ Secondly, Switzerland is independent in its peace commitment. It is not part of any military alliance, does not dispose of sufficient power in itself to impose solutions, nor has a colonial history. As such, Switzerland does not follow a hidden agenda. Moreover, given its multicultural population, democratic institutions and appreciated tradition to provide good offices, Switzerland possess the knowledge and first-hand experience to make a substantial contribution in peace promotion. ${ }^{94}$

The conception of peace promotion as an interest-driven policy and as a tool to assert its position within the international community is regularly used by the Swiss government. ${ }^{95}$ As a consequence, peace promotion is usually fuelled by security, economic stability and migratory movement interests. Other arguments are also used for an active peace promotion policy, such as the expectations of the international community towards Switzerland, or its sense of responsibility and solidarity towards civilians whose security is jeopardized by conflictual situations. ${ }^{96}$ Sometimes, the government states that Switzerland has to be active because the longstanding Swiss humanitarian tradition shares common values with peace promotion. ${ }^{97}$ However this language regime has to be taken with caution. Indeed, positions taken in official documents undergo scrutiny from other states. Thus Switzerland has an interest to reaffirm its appreciated role in peace promotion as a self-fulfilling prophecy. More importantly, the documents undergo the scrutiny from the Swiss electorate. Convincing them that any foreign policy objective is well funded is especially important as direct democracy give them a possibility to impede, even to forbid government activities.

${ }^{89}$ Ibid.

${ }^{90}$ Ibid.

${ }^{91}$ Graf et al., Conclusions, 410.

${ }_{92}$ Switzerland, Federal Council, Swiss Foreign Policy Strategy 2016-9: Federal Council report, 21.

${ }^{93}$ Ibid.

${ }^{94}$ Ibid.; Government of Switzerland, Federal Council, Message concernant la continuation de mesures de promotion de la paix et de la sécurité humaine 2012-2016, June 29, 2011 (FF 11.045), 5893-5896.

${ }^{95}$ For instance: Switzerland, Federal Department of Foreign Affairs, For Peace, Human Rights and Security, 3; Switzerland, Federal Council, Message concernant la continuation de mesures de promotion de la paix, 5887-5888; Government of Switzerland, Federal Council, Message sur la coopération internationale 2017-2020, February 17, 2016 (FF 16.022), 2459.

${ }^{96}$ Switzerland, Federal Department of Foreign Affairs, For Peace, Human Rights and Security; Switzerland, Federal Council, Message sur la coopération internationale 2017-2020, 2459.

${ }^{97}$ For instance: Switzerland, Federal Council, Message concernant la continuation de mesures de promotion de la paix, 5886. It is interesting to note that this document even goes as far as to imply that peace promotion is vital to preserve Switzerland's neutral status, for more information on this, see 5879 of this document. 
Currently, with a majority of the population convinced of the necessity of Switzerland's neutral status, and a strong conservative political party traditionally against international involvement, the electorate can be the main detractor of an active Swiss foreign policy.

Swiss peace promotion is presented in a general and to some extent programmatic document pertaining to Switzerland's commitment for peace, human rights and security. ${ }^{98}$ More importantly, the Federal Council has to review past peace promotion activities and has to present new orientation and strategies to the Parliament, which in turn will vote an according framework-credit. For the upcoming credit term (2017-2020), peace promotion measures are for the first time part of the more general framework of Switzerland's international cooperation. For this credit term, 230 million CHF have been allocated to peace promotion and human security activities. ${ }^{99}$

According to the coherence and efficiency principles, Switzerland is active in regions and themes representing a special interest for the country and where its activities are likely to have a substantial impact and make a difference. ${ }^{100}$ The government, however, is reticent to define a longterm peace promotion policy. It considers that peace promotion strategies should be progressive, innovative and flexible to best suit evolving conflictual context and partnerships with relevant actors. $^{101}$ Notwithstanding this concern, thematic and geographic priorities are defined and regularly updated. The Human Security Division, in charge of peace promotion, is in priority active in sub-Saharan Africa, North Africa, in the Middle East, within the Organization for Security and Cooperation in Europe, and in several countries in Asia and Latin America. ${ }^{102}$ Moreover, the HSD works mainly in four areas: peace policy, which aims to resolve conflicts through dialogue); to further develop humanitarian policy to ensure a better protection of civilian during armed conflicts; to strengthen and promote human rights; and lastly, regarding migratory policy, to better protect migrants and internally displaced people, and fight against human trafficking. ${ }^{103}$

\section{E. Switzerland's Approach to Preventing Mass Atrocities and Genocide}

Prevention of mass atrocities and genocide are part of Swiss peace promotion policy. Since 2003, Switzerland has taken note of the principles developed by Louis Joinet in a report to the United Nations Human Rights Commission. Joinet delimitated four key areas for action: the right to know, the right to justice, the right to reparation and the guarantee of non-recurrence. ${ }^{104}$ Switzerland has subsequently focused in these four areas in situations of serious violations of human rights and international humanitarian law. The underlining idea has been to avoid repetition of conflicts and other atrocities.

Working within this conceptual framework, in 2003, the FDFA's Human Security Division, which is subordinated to the Directorate of Political Affairs, began to develop a series of activities pertaining to dealing with the past and the prevention of mass atrocities and genocide. The HSD has focused these efforts on four particular areas of interest: peace, migration, humanitarian policy and human rights. ${ }^{105}$ Swiss activities for preventing mass atrocities and genocide were undertaken by the HSD peace promotion division. Given Joinet four key areas of action and the evolution of the international circumstances, it became clear that the complexity of these activities called for an interdepartmental approach. In April 2011, the FDFA direction decided to create a new

\footnotetext{
${ }^{98}$ Ibid.

${ }^{99}$ Switzerland, Federal Council, Message sur la coopération internationale de la Suisse 2017-2020, 2454.

${ }^{100}$ Switzerland, Federal Council, Message concernant la continuation de mesures de promotion de la paix, 5889.

${ }^{101}$ Ibid., 5897.

${ }^{102}$ Countries are selected following a set of criteria laid out in: Switzerland, Federal Council, Message sur la coopération internationale de la Suisse 2017-2020, 2327-2328.

${ }^{103}$ Ibid., $2464-2466$.

${ }^{104}$ United Nations, Economic and Social Council, The Administration of Justice and the Human Rights of Detainees, June 26, 1997 (UN Doc. E/CN.4/Sub.2/1997/20).

${ }^{105}$ Government of Switzerland, Federal Department of Foreign Affairs, "Human Security Division," January 14, 2018, accessed February 2, 2018, https://www.eda.admin.ch/eda/en/home/das eda/organisation deseda/direktionenabteilungen/politische direktion/ams.html.
} 
entity: the Task Force for dealing with the past and the prevention of atrocities (hereinafter cited as the Task Force) ${ }^{106}$

The Task Force is responsible for ensuring that the Swiss strategy pertaining to dealing with the past and preventing atrocities is coherent and consistent across the FDFA. While formally attached to the HSD, the Task Force currently consists of eight experts distributed across the FDFA's various departments. They are based within the HSD, the Political Affairs Directorate's International Organization Division (where they follow discussions happening in international fora and elaborate Swiss positions), the Swiss Agency for Development and Cooperation, and the Directorate of Public International Law (where they focus for instance on the complementarity between local, regional and international justice systems). The Task Force's head office and Special Envoy, who typically chairs international committees when the need arise, are based within the HSD. The eight experts work together on operational tasks and meet bimonthly to review current activities.

The Task Force's one-year annual planning is defined by a Steering Committee composed of the Ambassadors who head each expert's department. They issue an internal annual plan that lays out projected working over the coming twelve months. In addition to this yearly framework, the Steering Committee also reviews the work undertaken by the Task Force twice a year (mid-term and end of term review). Credits for the Task Force are included within the human security credit, which is part of the global framework-credit for Switzerland's international cooperation.

On a bilateral level, the Task Force has also been active in conflict and post-conflict situations, as well as in countries undertaking a political transition from authoritarian regimes. Its overall aim has been to bring about reconciliation in post-conflict societies, where tragic past events can create smoldering resentments. This resentment, in turn, if left unchecked, can lead to social tensions, a resurgence of violence, and can go as far as the commission of mass atrocities and genocide. By reestablishing social cohesion and having a deterrent effect, dealing with the past is closely linked to the prevention of mass atrocities and genocide.

The Task Force's conceptual framework of action has been constructed in a comprehensive and holistic manner, based on the four key areas set out by Joinet's original principles and subsequent recommendations. ${ }^{107}$ The idea behind the holistic approach is that the four pillars suffer from mutual influence and are interdependent. As a consequence, the Task Force works on a long-term basis to reconstruct social cohesion between victims and perpetrators. ${ }^{108}$ Its goal is to bring about reconciliation by contributing to a conducive environment to facilitate dialogue and by providing experts. This does not mean that the Task Force is always active in each pillar. It will usually analyze the situation as a whole, taking into account the four pillar, and subsequently tailor its activities to better fit each situation. As such, it is difficult to layout an exhaustive catalogue of activities undertaken by the Task Force, as it is constantly evolving, based on needs and means at disposal. A tentative list can however be established according to the Task Force's conceptual framework and past activities: concerning the right to know, the Task Force works closely with various fact-finding and truth commissions, on the safeguarding and the publication of archives, and provides assistance to the search for missing persons. Concerning the right to justice, it works closely with local, regional and international ad hoc tribunals as well as the International Criminal Court. Concerning the right to reparation, it provides assistance to ensure the restitution of goods, individual and collective reparation as well as psychosocial counseling, public apologies and erection of memorials. Finally, concerning the guarantee of non-recurrence, it provides assistance to disarm, demobilize and reintegrate combatants, to hold elections and reform institutions, to reform the security sector and the judiciary system, and to ensure no human rights violations or war crimes perpetrators hold a position of power, for instance within the armed force or the

\footnotetext{
${ }^{106}$ While it seems unsure why the form of "Task Force" has been chosen for the new entity, favouring a nomenclature featuring "dealing with the past" over "transitional justice" was a political choice. Indeed, it was thought that the former benefits from a wider scope than the later, and allows two approaches focusing on victims' rights on one hand, and states obligations on the other.

${ }^{107}$ Swisspeace, Un Cadre Conceptuel pour le Traitement du Passé. Bern: Swisspeace Essentials, 2014, 2.

${ }^{108}$ Ibid., 2.
} 
police (vetting) ${ }^{109}$ The holistic nature of the Task Force is a direct consequence of Joinet's principles, which set out individual right of the victim (or the family of the victim), collective rights for the society, and the duty for the state to ensure these rights are guaranteed and implemented. ${ }^{110}$

It is important to stress that the Task Force's bilateral activities are solely consent-based and only launched upon request. No action will be undertaken without official consent from the State where it takes place. While it incidentally safeguards the principle of non-interference, consent logically enhances the probability of success of any activities aiming to diffuse a tense situation.

There is no official procedure for establishing a program within a country: sometimes first contact is made through embassies, but it can also be made directly by or through the Task Force's head office in Bern. In the countries where the Task Force is active, a human security adviser is usually attached to the staff of the local Swiss embassy and serves as the focal point for the HSD experts. The exact nature of the Task Force's work is extremely diverse, and is organized to best suit each national context. Switzerland currently supports several initiatives, in particular the Philippines, Guatemala, Columbia, Bosnia, Serbia, Kosovo, Ukraine, Burundi, Mali, Chad, and the Middle East. The geographic areas of action change over time, depending on the evolution of international and national situations. It provides financial, logistical, and/or political support, and serves in an active advisory capacity. ${ }^{11}$

The Task Force works closely with the HSD's peace promotion section and the geographic sections of the Directorate of Political Affairs to implement its activities. As a practical consequence, even if the Task Force is not bound to work only in specific countries, it is somewhat constrained by priority countries listed within Switzerland's foreign policy. Priority countries are strategically important to Switzerland, and thus any support provided to deal with the past and prevent future mass atrocities fits within Switzerland's broader foreign policy goals. That was for instance the case in the Balkans, where Swiss programs were driven primarily by interests due to the Balkans' close geographical location as well as by the conflicts' migration impact. There have also been instances where countries with historical ties to Switzerland, and where Switzerland has had an active diplomatic and economic presence, have turned to Switzerland when facing difficulties and called on the Task Force for support. Colombia provides an excellent example: Switzerland extended its good office during the conflict and is now supporting the Historical Memory Centre.

Considerations pertaining more specifically to prevention of mass atrocities and genocide led Switzerland to the co-organization of four regional forums in Argentina (2008), Tanzania (2010), Switzerland (2011) and Cambodia (2013). They have been aiming to raise awareness among participating governments about genocide prevention as well as to strengthen their capacities in this field by sensitizing them to early warning signs and encourage timely and efficient responses. ${ }^{112}$

At the initiative of Switzerland, these forums led to the establishment in 2013 of a boarder initiative: the international network Global Action Against Mass Atrocity Crimes (hereinafter cited as GAAMAC). GAAMAC's role is twofold: it has been conceived as a platform to exchange information on best practices; it also provides assistance to build states capacities to prevent mass atrocities as well as to develop and to implement national preventive strategies. In addition, GAAMAC also aims to serve as a bridge-builder between the Responsibility To Protect and the genocide prevention communities. In fact, the name GAAMAC was specifically chosen with an eye to attempting to comprehensively incorporate the themes underlying both the Responsibility To Protect and genocide prevention. To date, GAAMAC has hosted two international conferences:

\footnotetext{
${ }^{109}$ Ibid., 4-12; Government of Switzerland, Federal Department of Foreign Affairs. "Switzerland's framework for action," January 27, 2017, accessed February 7, 2018, https://www.eda.admin.ch/eda/en/home/foreign-policy/human-rights/ peace/dealing-with-past/conceptual-framework.html.

${ }^{110}$ Swisspeace, Un Cadre Conceptuel pour le Traitement du Passé, 4.

${ }^{111}$ Government of Switzerland, Federal Department of Foreign Affairs, "Dealing with the past," November 27, 2017, accessed February 7, 2018, https://www.dfae.admin.ch/eda/en/home/foreign-policy/human-rights/peace/dealing-withpast.html.

${ }^{112}$ Government of Switzerland, Federal Department of Foreign Affairs, "Preventing atrocities," November 11, 2017, accessed February 4, 2018, https://www.eda.admin.ch/eda/en/home/foreign-policy/human-rights/peace/genocide. $\underline{\mathrm{html}}$.
} 


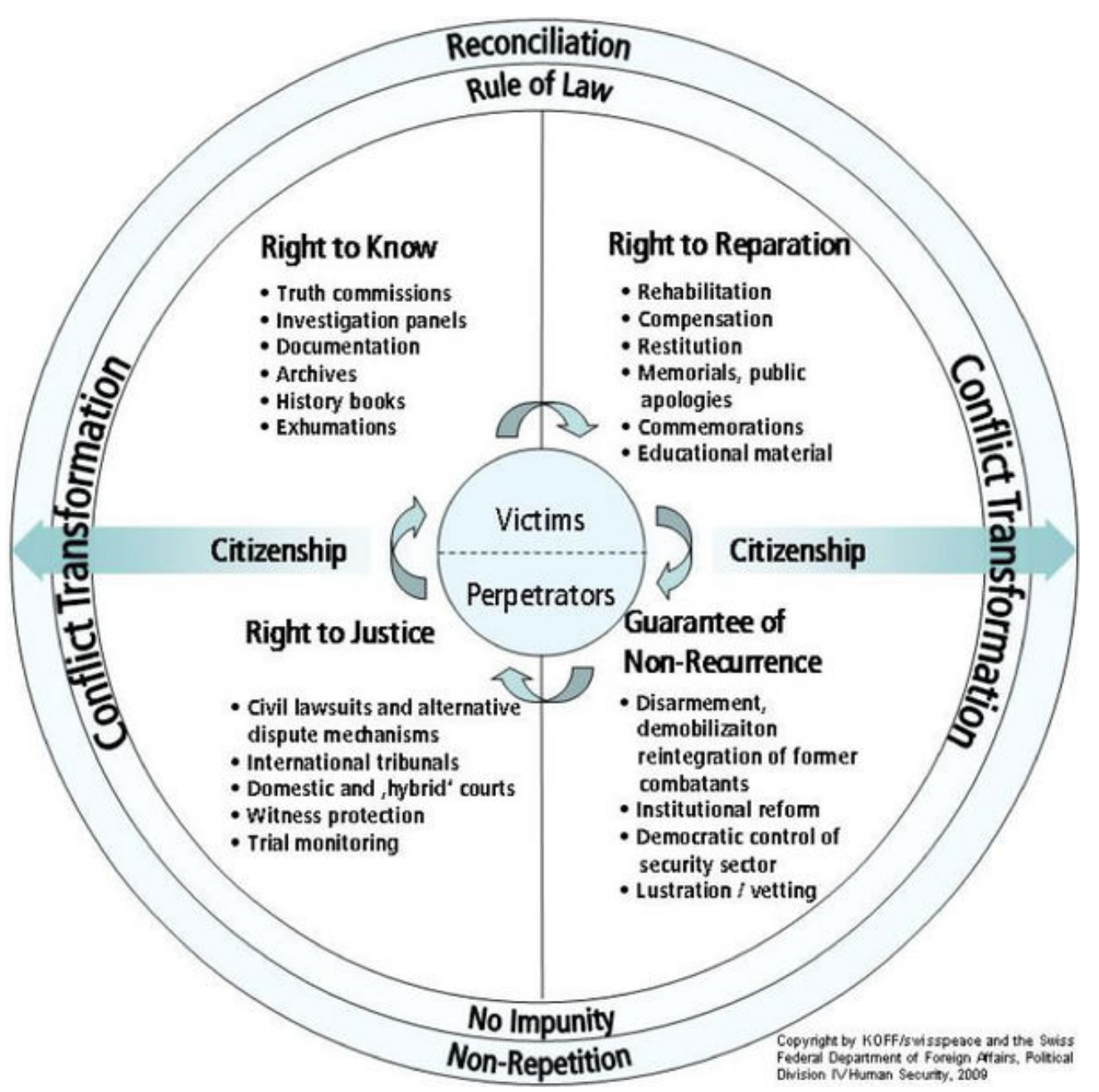

Figure 1. Source: http://www.dealingwiththepast.ch/about/approach.html.

GAAMAC I in Costa Rica (2014) and GAAMAC II in the Philippines (2016). Switzerland chairs the network's Steering Committee since its establishment. ${ }^{113}$

In addition to GAAMAC, the Task Force is also engaged on a multilateral level in diverse international fora, working especially closely with the UN's Secretariat. Swiss diplomats have actively promoted and assisted in the development of several new ideas and concepts pertaining to the prevention of mass atrocity crimes. For instance, Switzerland launched diplomatic initiatives in 2005, 2008, 2009, 2012 and 2016 which led respectively to the adoption of resolutions by the UN Commission on Human Rights and by the Human Rights Council aimed at strengthening human right and justice in transitional processes. Switzerland also supported the establishment of a mandate for a UN Special Rapporteur For The Promotion Of Truth, Justice, Reparation, and Guarantees of Non-recurrence. ${ }^{114}$ Within the staff of the Special Rapporteur, Switzerland financed one expert's position. At the country level, Switzerland was at the origin of the resolution A/HRC/33/L.10 of the Human Rights Council, adopted in September 2016. It requests a joint study from the United

${ }^{113}$ Global Action Against Mass Atrocity Crimes, “History," accessed September 4, 2016, http://www.gaamac.org/aboutgaamac/history.

${ }^{114}$ Government of Switzerland, Federal Department of Foreign Affairs, "Dealing with the past," November 27, 2017, accessed February 7, 2018, https://www.dfae.admin.ch/eda/en/home/foreign-policy/human-rights/peace/dealing-withpast.html. 
Nations Special Rapporteur on the promotion of truth, justice, reparation and guarantees of nonrecurrence and the Special Adviser of the Secretary-General on the prevention of genocide. The study should address the contribution of transitional justice to the prevention of gross violations and abuses of human rights as well as serious violations of international humanitarian law and their recurrence. The Task Force also works with other international organization on an ad hoc basis, providing for instance, experts to the European Union at various times.

Since 2010, the Task Force has also organized an invitation-only advanced lecture on dealing with the past and the prevention of mass atrocity crimes. The goal of the course is "to provide participants with in-depth knowledge of fundamental Dealing with the Past concepts, mechanisms, best practices and lessons learned, as well as an opportunity to engage in a process of critical reflection about different approaches to Dealing with the Past in post-conflict contexts." 115 The course brings together civil society professionals and state officials from various countries (usually around five states). While nationals are dispersed during the course, the course usually ends with a group work conducted by nationals of the same country, which allows them to reflect on the elaboration of a road map for their national context. Over the years, interest in the advanced lectures has grown. Since 2015, lectures can be offered for specific context on a case-by-case basis. Switzerland views the course, at least in part, as a way to construct and consolidate a network of experts on dealing with the past and mass atrocity crimes prevention. ${ }^{116}$

Since its establishment, the Task Force has been confronted with a number of diverse challenges. Some challenges can be attributed at least partly to the subject itself. With the rise of demands over the past few years as well as the expansion of GAAMAC, the Task Force is victim of its own success: it currently lacks the financial and personal resources to address all of the demands being placed on it. As a consequence, the Task Force recently developed an internal set of criterion against which to accept or refuse requests for help. Switzerland's foreign policy principles of efficiency and coherence may provide broad guidelines in this establishment. They must however be used in accordance with the principles of solidarity and responsibility. Establishing an assessment process is not an easy task and raises multiple practical and ethical questions.

Challenges can also be due to the holistic approach followed. As a matter of fact, dealing with the past and the prevention of mass atrocity crimes are extremely sensitive subjects in usually extremely tense contexts. Activities must be the result of a good comprehension and inclusive planning, taking carefully into account the conflictual situation and possible impacts to avoid any escalation of violence. They must be sensitive and adaptable to the evolving conflicts dynamic in diverse political, social and economic contexts. Moreover, to avoid problems due to the lack of legitimacy and unfitting planning, a "bottom-up" approach elaborated with the inclusive participation of significant national actors should ideally be followed. While a bottom-up approach allows for the establishment of a fitting mechanism, it entails the challenge of defining measures and mechanisms for each situation which could contribute to the transformation of a conflict, to reconciliation and to the rule of law. These measures and mechanisms should not lead to impossible expectations, but should be realistic and take into account available resources, often scarce in conflict or post-conflict context. ${ }^{117}$

\section{F. Prevention of Mass Atrocity Crimes in The Light of Swiss Neutrality and Foreign Policy}

The general overview of the content and evolution of Swiss foreign policy underlined the shift operated in the beginning of the nineties. By adopting an active neutrality, as well as defining peace promotion as one of the five constitutional goals of Switzerland's foreign policy, the Federal Council paved the way for the development of peace promotion activities. Moreover, peace promotion was actively developed as a niche diplomacy substitute for the ailing Swiss good offices. Peace

\footnotetext{
${ }^{115}$ Swisspeace, "Goals," Dealing with the Past: An Advanced Learning Course for Professionals, accessed September 4, 2016, http://www.dealingwiththepast.ch/about/goals.html.

${ }^{116}$ For more information: Swisspeace, “Dealing with the Past Course," Dealing with the Past: An Advanced Learning Course for Professionals, accessed September 4, 2016, http://www.dealingwiththepast.ch/course.html.

117 Swisspeace, Un Cadre Conceptuel pour le Traitement du Passé, 14-18.
} 
promotion thus developed and specialized in different areas where Switzerland, in conformity with its foreign policy principles, could be efficient and make a substantial impact. Swiss characteristics shaped this development. The Balkans war led to more peace promotion activities focused on dealing with the past and genocide prevention, as a way to ensure Switzerland's security and economic and migratory stability, ultimate goal of Swiss foreign policy. Neutrality and direct democracy also influenced this development. Military peace promotion was forbidden by popular plebiscite in 1994 as a result of the right wing Swiss People Party's action for an "Independent and Neutral Switzerland." Participation in UN and OSCE peace operations has subsequently been accepted in 2001, under the condition that it should be conform to Switzerland's foreign policy and that Swiss participants would only carry a weapon for self-defence and not engage in any enforcement action. ${ }^{118}$ This partial acceptance does not allow Switzerland to be a prominent actor in military peace promotion, which could also explain the strong focus given to civilian peace promotion. These multiple factors and slow evolution led to the establishment of the Task Force, a niche diplomacy that seems to be in concordance with the values and principles of Swiss foreign policy, as well as its neutrality. But are the Task Force activities really compatible with the flexible and evolving conception of neutrality? How can neutrality influence the future of Swiss genocide and mass atrocities prevention?

The following analysis aims to first establish whether the Task Force activities abide to neutrality law in different conflicts configurations. In a second phase, they will analysed through the lens of the policy of neutrality and its defining characteristic, namely the Swiss national role conceptions as defined by Graf and Lanz. The last part of the analysis will address the future of mass atrocities and genocide prevention in the light of the conclusion reached at this stage.

As we saw above, the juridical acceptation of neutrality is relatively narrow and forbids the neutral state to intervene in armed conflicts. One can ask whether there should be a special exception excluding the application of neutrality in case of mass atrocity crimes and genocide. During the Kosovo war, Switzerland was confronted to this problematic through NATO's humanitarian intervention. ${ }^{119}$ Switzerland addressed the hypothetical applicability of neutrality law to military measures taken as a reaction to mass atrocity crimes or genocide, in a case where the UN Security Council did not endorse the measures. The Federal Council made a distinction between ethics and neutrality. From the ethical point of view, the Council affirmed that States are expected to lend support to populations suffering or being exposed to grave mistreatment. In terms of neutrality, however, the Council recognized that Switzerland would have to decide whether or not neutrality law would be applicable. The Council considered it hardly conceivable that an unlawful use of force would not trigger the application of neutrality law, whereas the exclusion of neutrality, if the use of force was undertaken in accordance with international law, was a disputable matter. In that case, the Council fleshed out how the decision should be made. It "[...] necessitates a careful and comprehensive weighing up of all the interests involved. In so doing, the prevention of and action against international crime, respect for the prohibition of force and consolidation of the UN's system of collective security will be as important as Switzerland's interest in a coherent, consistent policy which - at least at present-seems completely guaranteed only by a purely formal approach (i.e., existence of a decision by a legitimized organ)." ${ }^{\prime 20}$ No subsequent decisions or positions were taken in that regard. While the establishment of a new circumstance excluding the applicability of neutrality law is still open, it is however not (yet?) recognized by Switzerland.

As cases of genocide and mass atrocity crimes do not automatically exclude the application of neutrality law, the common rules for its application and content must be analyzed to know whether it forbids prevention activities. The Swiss government reaffirmed several times that the application of neutrality law was limited to international armed conflict, in situations where the UN Security

\footnotetext{
${ }^{118}$ Government of Switzerland, State Chancellery, Votation populaire du 12.06.1994, accessed September 4, 2016, https://www. admin.ch/ch/f/pore/va/19940612/index.html.

119 The label of humanitarian intervention is controversial but as it is the terminology used, with caution, by the Federal Council, the analysis will use this nomenclature without questioning it.

${ }^{120}$ Government of Switzerland, Interdepartmental Working Group, Swiss Neutrality in Practice - Current Aspects: Report of the interdepartmental working group, August 30, 2000, 16.
} 
Council did not legitimize the use of force of one State. ${ }^{121}$ This understanding means that genocide and mass atrocity crimes prevention activities are thus always compatible with neutrality law if 1) they happen in a strictly internal tensions context (civil war, political transition, etc.) or 2) if the Security Council has endorsed one party, in accordance with international law. While legal, such activities must still be confronted to the prevailing policy of neutrality, as it will be done below.

The lawfulness of the Task Force activities in case of other conflict configurations is less clear. In the case of an international armed conflict where no side's use of force has been legitimized by a resolution of the UN Security Council, Switzerland considers that neutrality law forbids Switzerland to militarily support a belligerent State. ${ }^{122}$ This interdiction is a corollary of the obligation of equal treatment, core obligation of neutrality law. ${ }^{123}$ However, it is nuanced: the principle of equal treatment only applies to acts of the neutral state which are of military relevance to the parties of the international armed conflicts. ${ }^{124}$ In a hypothetical situation where State A and $\mathrm{B}$ are opponents in an international armed conflict, State $\mathrm{A}$ is at the verge of committing mass atrocities against State B's nationals. If we consider that leading prevention activities provides a military advantage to State B or military impede State A, then, by acting, Switzerland may violate its neutral state's duty of equal treatment. While preventing mass atrocities committed against State B's troops logically impacts the outcome of the conflict and should be considered as giving at least an indirect military advantage, the status of crimes targeting civilian is less clear. Indeed, given the psychological impact mass atrocities and genocide are likely to have on the victim State's nationals, as well as how they weaken the victim State's apparatus and economy, they could be considered as having an indirect effect on the military capacity of the victim State. As the Swiss government recognized in its 2005 Neutrality Report, it is debatable how far the law of neutrality governs measures which could indirectly influence the conflict to the advantage or disadvantage of one conflict's party. ${ }^{125}$ While some argue that a broad notion of military support should be retained, which scope includes all indirect military support, the general acknowledged duties of neutral States, including Switzerland, tend toward limiting neutrality law to its military core. According to this understanding, providing indirect military support, limited to the principle of equal treatment in trade, is forbidden. ${ }^{126}$ As such, activities of prevention may lawfully take place in this context. They must however still undergo the policy of neutrality scrutiny.

The same debatable analysis has to take place in the case of an internationalized internal armed conflict. In that configuration, State B might suffer from an internal conflict against a rebel group, whose committing mass atrocities or a genocide. State A and State B are not directly in conflict with each other. However, State A might be providing assistance to the rebel group in State B. It is unclear if this configuration enters the scope of application of neutrality law. If the international element of the internal armed conflict is deemed sufficient to trigger the application of neutrality law, then the same analysis has to be made to define if undertaking prevention activities are violating the neutral state's duties.

As we have seen thus far, activities of prevention of mass atrocities might be taken in accordance with neutrality law. However, if neutrality law does not seem to forbid all prevention activities, a State can still politically choose to go further by adopting a stronger policy of neutrality. Any mass atrocity crimes and genocide prevention activities that were deemed legal according to neutrality law must also be compatible with Switzerland's policy of neutrality to be carried out. As aforementioned, Swiss policy of neutrality aims to give credibility to Switzerland's position as a neutral state. As such, bilateral activities - if led in purely internal armed conflict context, or, in case of international armed conflict, if the activities do not fall in the scope of neutrality law-as

\footnotetext{
${ }^{121}$ Ibid., 13 and 16; Government of Switzerland, Federal Council, Neutrality Under Scrutiny in the Iraq Conflict, December 2, $2005,2$.

${ }_{122}$ Switzerland, Federal Council, Neutrality Under Scrutiny, 12.

${ }^{123}$ Paul Seger, "The Law of Neutrality", in The Oxford Handbook of International Law in Armed Conflict, ed. Andrew Clapham et al. (Oxford: Oxford University Press, 2014), 257.

${ }^{124}$ Ibid.

${ }^{125}$ Switzerland, Federal Council, Neutrality Under Scrutiny, 12.

${ }^{126}$ Ibid., 13.
} 
well as multilateral activities irrespective of an armed conflict, should be analyzed through the lens of the neutrality policy.

Given its nature of flexible tool, there is no precise definition of what the policy of neutrality entails. Since the shift operated in 1993, Switzerland is following an active neutrality to answer global threat-in opposition to the isolationism prevailing during the Cold War Era-and should be realized "in the service of peace." ${ }^{127}$ This conception is twofold: on the one hand, to compensate the loss of Switzerland's importance for providing good offices, neutrality should be interpreted in a way that allows a stronger peace promotion policy. On the other hand, the Federal Council affirms that neutrality is subordinated to the solidarity principle, which underpins Swiss foreign policy. ${ }^{128}$ The Council concludes that "Switzerland will continue to direct its neutrality toward humanitarian and peaceful goals. [...] In shaping its neutrality, it will also take the needs of international solidarity into account in order to serve the community of nations. Swiss neutrality must remain a peace-promoting factor both in Europe and throughout the world."129

However, this ambiguous and vague definition of active neutrality does not necessarily mean that mass atrocities and genocide prevention are compatible with the current Swiss policy of neutrality. By using a deliberatively vague language in 1993, the Federal Council allowed the expansion of peace promotion activities, while keeping a leeway to forbid any future politically delicate activities in the name of neutrality. This seems to be confirmed by subsequent practice. Instead of better define what the new conception of active neutrality meant, the Federal Council used the same language on policy of neutrality in its two subsequent throughout analysis in 2000 and in 2005. In 2005 however, the Council introduced a slight change to its reaffirmed position, stressing that "neutrality should not be equated with indifference" and considered that Switzerland activities aiming to increase the respect of international humanitarian law by the parties to the Iraqi conflict were deemed compatible with the Swiss policy of neutrality ${ }^{130}$ An analogy could probably be drawn from this consideration for the Task Force multilateral activities, such as GAAMAC, as its aims are similar. On a bilateral level, it seems harder to conclude that the Federal Council's previous positions expressly allows Switzerland to play a more active role within a country party to an international armed conflict.

Given the lack of clear and written policy of neutrality regarding mass atrocity crimes and genocide prevention, and its evolving and fluctuant nature, we have to take a closer look on what is shaping it, namely Switzerland's national role conceptions - which stem from neutrality and, as well as the aims of neutrality.

As mentioned earlier, two main and seemingly contradictory national role conceptions are shaping Switzerland policy-making. The first one is the isolate national role conception-the tendency to fear and avoid international relations. The second one is Switzerland's mediatorintegrator national role conception, which can to some extent be linked to its less pronounced bridge-builder and defender of faith national role conception. The inherent nature of mass atrocities and genocide prevention seems to be the logical extension of the mediator-integrator national role conception, and be in direct contradiction with its isolate national role. If we consider it to be the case, then the existence of the Task Force implies that the mediator-integrator is actually stronger than the isolate national role conception in the political sphere-and, through direct democracy, the public sphere - as it can afford to contradict it.

However, another reading of the situation is possible. As underlined by Goetschel's dualism between "high" and "low" politics, not every international relation is following an isolationist trend. Mass atrocity crimes and genocide prevention, though primarily aiming at avoiding the commission of atrocities abroad, are part of Swiss peace promotion policy and thus obey its interest-driven logic, fuelled by security, economic stability and migratory movement interests. Its secondary aim is thus to ensure Switzerland's stability and security, as well as its well-being.

\footnotetext{
${ }^{127}$ Switzerland, Federal Council, White Paper on Neutrality, Annex to the Report, 11.

${ }^{128}$ Ibid.

${ }^{129}$ Ibid., 27.

${ }^{130}$ Switzerland, Federal Council, Neutrality Under Scrutiny, 14.
} 
Because the work of the Task Force is not directly affecting Switzerland's security, but only has a future, negative and difficult to quantify impact (in the sense that it does not improve but allows the situation to remain unchanged), it can be argued that mass atrocities and genocide prevention should be labeled as "low" politics.

This second understanding seems to be confirmed by three facts. First, there is no available document issued by the government to confirm that the Task Force's activities are compatible with neutrality. An internal analysis might have been realized, however, the lack of published document on the matter seems to attest that government policy-makers did not believe it would be in contradiction with the Swiss population conception of neutrality. Second, while neutrality is a recurrent subject of parliamentary interpellation, no parliamentarian asked the Federal Council to justify any genocide and mass atrocities prevention activities in regard to neutrality. Third, there has been no plebiscite regarding civilian peace promotion activities, in opposition to military peace promotion. The lack of reaction raised by prevention activities seems to confirm that they must be considered as low politics, which are not limited by the isolate national role conception.

In conclusion, by following the current trend to limit the neutral state's obligations to its military core, Switzerland excludes mass atrocities and genocide prevention activities from the scope of neutrality law. Moreover, as an expression of the mediator-integrator national role conception or as a matter of low politics, they thus appear to be in conformity with the current Swiss policy of neutrality.

What does it mean for the Task Force future? As the policy of neutrality is conceived as a flexible instrument, its evolution is likely to influence Switzerland's peace promotion and the Task Force's existence. Changing international circumstances may lead the Federal Council to reinterpret Switzerland's neutrality. One possible development would be to go even further than the current active neutrality, interpreting Switzerland's policy of neutrality and neutrality duties in a narrower sense. In that scenario, the activities of the Task Force would remain unchallenged.

On the contrary, if Switzerland evolves toward a strict neutrality due to the resurgence of a neighboring threat, similar to the integral neutrality of the Cold War, it would affect them to a certain extent, depending on the degree of the evolution. A first step would be to adopt a broad definition of what constitutes a military advantage in neutrality law, effectively forbidding prevention in international armed conflict. A second step would be the adoption of a strict policy of neutrality. In that configuration, the change in the political climate would likely result in a stronger isolate national role conception over its mediator-integrator rival.

Two scenarios might unfold in this case: if mass atrocity crimes and genocide prevention stems from the weakened mediator-integrator conception, the reinforcement of the isolate national role conception will probably lead to discard prevention in favor of a more isolate behavior. If however, prevention activities are, as we argued, part of Goetschel's low politics, then it is possible that they would not be challenged by the strengthening of the isolate conception. Given their inherent international nature however, it seems unlikely that they would not attract further notice. The Federal Council would probably have to realize an in-depth analysis of prevention activities in the light of their utility to Switzerland and the international community, and their potential contradiction to the aims of a strict understanding of neutrality. In case of clashing interest, the Task Force's existence would probably be in peril. While it could be argued that the indirect security and stabilizing effects of prevention may be a sufficient replacement of neutrality, it seems unlikely that Switzerland would abandon neutrality in favor of prevention. Indeed, prevention, while it might ensure security, would not be able to ensure social cohesion by providing Swiss population with a distinct identity. Moreover, national role conceptions at the basis of prevention - mediatorintegrator, bridge-builder and to a certain degree defender of the faith-are a direct consequence of neutrality. It seems thus extremely difficult to replace neutrality by prevention, as neutrality is indirectly one of the justifications of Swiss prevention activities.

\section{G. Conclusion}

Before the end of the Cold War, Switzerland was following a strict policy of neutrality which tended toward isolationism. The shift from a bipolar to a multipolar world led to a new interpretation of the policy, which allowed for the development of peace promotion activities. Peace promotion 
was then enshrined in the revised Federal Constitution as one of the five goals of Swiss foreign policy. Two decades later, a specialized and cross-departmental entity - the Task Force for Dealing with the Past and Prevention of Atrocities-was created. This specialization could be the result of multiple factors: the diminishing role of the good offices, the need to reassert Switzerland's position in the international community by investing in new diplomatic niches, the impossibility to develop military peace promotion as a consequence of direct democracy, etc. After a few years of working both at the multilateral and bilateral level, following an inclusive and holistic approach, the Task Force has to overcome a new challenge induced by the lack of resources and lay out a set of criterion to accept or decline help request.

At the same time, Switzerland neutral status did not lose its force. The Federal Council reaffirmed several times that neutrality has proven its capacity to protect Switzerland security and stability. As we saw above, neutrality is thus both what allowed prevention activities to flourishas a consequence of the mediator-integrator national role conception-and what can potentially limit them, as a consequence of the isolate national role conception. As we demonstrated, the current interpretation of Swiss neutrality law and policy is compatible with mass atrocities and genocide prevention. However, if new threats considered grave enough to adopt a stricter policy of neutrality were to arise, it could have serious consequences on the existence of the Task Force. A broader understanding of the interdiction to provide military advantages to the belligerents, including in its scope indirect advantages, may lead to the illegality of prevention activities. The strengthening of the isolate national role conception could also have an enormous impact on these activities. If prevention activities are based on the mediator-integrator national role conception, they may stop in favor of a more isolate behavior. However, if, as we argued, they are considered to be part of Goetschel's low politics, they may survive to the strengthening of the isolate national role conception.

Regardless of the national role conception's affiliation of mass atrocity crimes and genocide prevention, the cessation of the Task Force activities must also be analyzed regarding Switzerland's international relations. Indeed, neutrality proves a lack of hostility, but peace promotion proves usefulness vis-à-vis greater powers. ${ }^{131}$ In the light of Switzerland's candidacy for the Security Council in 2023-2024, niche diplomacy will surely be highly put forward to distinguish Switzerland from rival countries. In addition, as Switzerland is a small, almost absent, player regarding military peace promotion, it will probably counterbalance this weakness by an active, efficient, and, more importantly, specialized civilian peace promotion. As a consequence of its candidacy, Switzerland will probably intensify in the upcoming years its activities regarding genocide and mass atrocity crimes prevention, especially in multilateral fora.

\section{Bibliography}

Aeschimann, Stefan, Emmanuel Bichet, Christian Catrina, Bozena Huser, Urban Kaufmann, Sonja Margelist, Hansruedi Moser, Marco Oswald, Ruedi Plüss, Markus Rusch, Paul Seger, Jürg Stüssi-Lauterburg, Thomas Suremann, Anton Thalmann, and Sylvia Zemp. Swiss Neutrality. 4th ed. Bern: Communication DDPS, 2004.

Bothe, Michael. "The Law of Neutrality." In The Handbook of International Humanitarian Law, edited by Dieter Flecker, 571-604, 3rd ed. New York, Oxford University Press, 2013.

Cooper, Andrew and Timothy Shaw. "The Diplomacies of Small States at the start of the Twentyfirst Century: How Vulnerable? How Resilient?" In The Diplomacies of Small States: Between Vulnerability and Resilience, edited by Andrew Cooper and Timothy Shaw, 1-18. New York, Palgrave Macmillan, 2009. https://doi.org/10.1057/9780230246911 1

Gabriel, Jürg Martin. "The Price of Political Uniqueness: Swiss Foreign Policy in a Changing World." In Swiss Foreign Policy 1945-2002, edited by Jürg Martin Gabriel and Thomas Fischer, 1-22. London, Palgrave Macmillan, 2003. https://doi.org/10.1057/9780230500242 1

. “Neutralität für den Notfall: Der Bericht des Bundesrats Zur Aussenpolitik der Schweiz in den 90er Jahren." Swiss Political Science Review 1 (1995): 161-190.

${ }^{131}$ Graf and Lanz, Conclusions, 413. 
and Jon Fanzun. Swiss Foreign Policy: An Overview. Zürich: ETH Zürich - Forschungsstelle für Internationale Beziehungen, 2003.

Global Action Against Mass Atrocity Crimes. "History." Accessed September 4, 2016. http://www. gaamac.org/about-gaamac/history.

Goetschel, Laurent. "Foreign Policy." In Handbook of Swiss Politics, edited by Peter Knoepfel, Hanspeter Kriesi, Wolf Linder, Yannis Papadopoulos, and Pascal Sciarini, 571-591, 2nd ed. Zürich: Neue Zürcher Zeitung Publishing, 2007.

. "Neutrality, a Really Dead Concept?" Cooperation and Conflict 34 (1999): 115-139. https://doi.org/10.1177/00108369921961807

-------, Magdalena Bernath, and Daniel Schwarz. Swiss Foreign Policy: Foundations and Possibilities. Milton Park: Routledge, 2005.

Government of Switzerland. Federal Constitution of the Swiss Confederation, 18 April 1999, as of 1 January 2016. RS 101.

---------. "Human Security Division." January 14, 2018. Accessed February 2, 2018. https://www. eda.admin.ch/eda/en/home/das eda/organisation deseda/direktionen-abteilungen/ politische direktion/ams.html.

--------. Ordonnance sur l'organisation du gouvernement et de l'administration, 25 November 1998, as of 1 August 2016. RS 172.010.1.

-------.. Ordonnance sur l'organisation du Département fédéral des affaires étrangères, 20 April 2011, as of 24 March 2015. RS 172.211.1.

Government of Switzerland, Federal Council. "Good Offices: A Swiss Speciality" Speech, Valetta, September 15, 2015. Accessed October 3, 2016. https://www.admin.ch/gov/de/start/ dokumentation/medienmitteilungen.msg-id-60927.html.

--------. Message concernant la continuation de mesures de promotion de la paix et de la sécurité humaine 2012-2016. June 29, 2011. FF 11.045.

-------. Message sur la coopération internationale 2017-2020. February 17, 2016. FF 16.022.

------. Neutrality Under Scrutiny in the Iraq Conflict. December 2, 2005.

--------. Rapport sur la politique extérieure 2000, Présence et coopération: la sauvegarde des intérêts dans un monde en cours d'intégration. November 15, 2000. FF 00.09.

. Rapport de politique étrangère. June 15, 2007. FF 07.058.

---.-. Rapport sur la politique extérieure 2015. FF 16.009, January 13, 2016.

. Swiss Foreign Policy Strategy 2016-9: Federal Council report on the priorities for the 2016-19 legislative period. Bern: Federal Department of Foreign Affairs, 2016.

. White Paper on Neutrality, Annex to the Report on Swiss Foreign Policy for the Nineties. November 29, 1993. FF 1994 I 150.

Government of Switzerland, Federal Department of Foreign Affairs. "Dealing with the past." November 27, 2017. Accessed February 7, 2018. https://www.dfae.admin.ch/eda/en/home/ foreign-policy/human-rights/peace/dealing-with-past.html.

-----. For Peace, Human Rights and Security: Switzerland's Commitment to the World. Bern, 2012.

------.. "Good offices." December 18, 2017. Accessed February 7, 2018. https://www.eda.admin. ch/eda/en/home/foreign-policy/human-rights/peace/switzerland-s-good-offices.html. . "Organization of the FDFA." January 11, 2018. Accessed February 7, 2018. https://www. eda.admin.ch/eda/en/home/fdfa/organisation-fdfa.html.

. "Preventing atrocities." November 27, 2017. Accessed February 11, 2018. https://www. eda.admin.ch/eda/en/home/foreign-policy/human-rights/peace/genocide.html.

-. "Switzerland's framework for action." January 27, 2017. Accessed February 7, 2018. https:// www.eda.admin.ch/eda/en/home/foreign-policy/human-rights/peace/dealing-with-past/ conceptual-framework.html.

Government of Switzerland, Interdepartmental Working Group. Swiss Neutrality in Practice Current Aspects: Report of the interdepartmental working group. August 30, 2000.

Government of Switzerland, State Chancellery. Votation populaire du 12.06.1994. Accessed September 4, 2016. https://www.admin.ch/ch/f/pore/va/19940612/index.html. 
Graf, Andreas and David Lanz. "Conclusions: Switzerland as a paradigmatic case of small-state peace policy?" Swiss Political Science Review 19 (2013): 410-423. https://doi.org/10.1111/ spsr.12048

Green, Leslie. The Contemporary Law of Armed Conflict, 3rd ed. Manchester: Manchester University Press, 2008.

Holsti, Kalevi Jaakko. "National Role Conceptions in the Study of Foreign Policy." International Studies Quarterly 14 (1970): 233-309. https://doi.org/10.2307/3013584

Klöti, Ülrich. "The Government." In Handbook of Swiss Politics, edited by Peter Knoepfel, Hanspeter Kriesi, Wolf Linder, Yannis Papadopoulos, and Pascal Sciarini, 145-169, 2nd ed. Zürich: Neue Zürcher Zeitung Publishing, 2007.

Linder, Wolf. “Direct Democracy." In Handbook of Swiss Politics, edited by Peter Knoepfel, Hanspeter Kriesi, Wolf Linder, Yannis Papadopoulos, and Pascal Sciarini, 101-119, 2nd ed. Zürich, Neue Zürcher Zeitung Publishing, 2007.

Rickli, Jean-Marc. "Neutrality Inside and Outside the EU: A Comparison of Austrian and Swiss Security Policies after the Cold War." In Small States in Europe: Challenges and Opportunities, edited by Robert Steinmetz and Anders Wivel, 181-198. Surrey: Ashgate, 2010.

Seger, Paul. "The Law of Neutrality." In The Oxford Handbook of International Law in Armed Conflict, edited by Andrew Clapham and Paola Gaeta, 248-272. Oxford: Oxford University Press, 2014.

Swisspeace. "Dealing with the Past Course." Dealing with the Past: An Advanced Learning Course for Professionals. Accessed September 4, 2016. http://www.dealingwiththepast.ch/course.html. . "Goals." Dealing with the Past: An Advanced Learning Course for Professionals. Accessed September 4, 2016. http://www.dealingwiththepast.ch/about/goals.html. Un Cadre Conceptuel pour le Traitement du Passé. Bern: Swisspeace Essentials, 2014.

United Nations, Economic and Social Council. The Administration of Justice and the Human Rights of Detainees. June 26, 1997. UN Doc. E/CN.4/Sub.2/1997/20.

Vatter, Adrian. "Federalism." In Handbook of Swiss Politics, edited by Peter Knoepfel, Hanspeter Kriesi, Wolf Linder, Yannis Papadopoulos, and Pascal Sciarini, 77-99, 2nd ed. Zürich: Neue Zürcher Zeitung Publishing, 2007. 